Kajian Jurnalisme

ISSN 2549-0559 (cetak) ISSN 2549-1946 (online)

Volume 02 Nomor 02 Tahun 2019

\title{
Makna Jurnalisme Warga Bagi Jurnalis Warga Netcj.Co.Id
}

\author{
Muhammad Iqbal dan Nuryah Asri Sjafirah \\ Program Studi Ilmu Jurnalistik, Fakultas Ilmu Komunikasi, Universitas Padjadjaran, \\ E-mail: muhammad.iqbal8496@gmail.com
}

\begin{abstract}
Citizen journalism is a new genre compared to traditional journalism. However, the new one does not mean that it only appeared a year or two years ago. After being known through radio, citizen journalism has developed into the realm of television since it was introduced through amateur videos which aired on Metro TV news programs. Since 2014, NET TV has NET10 program and Netcj.co.id platform which carries the concept of citizen journalism that integrates each other. Although, citizen journalism is not something new, the netcj.co.id platform that accommodates the coverage of citizen journalists is still relatively new in Indonesia. Therefore, this study discusses the meaning of citizen journalists netcj.co.id about how they interpret the practice of citizen journalism and the role of a citizen journalist, the motives of netcj.co.id citizen journalists are sending the results of the coverage to the netcj.co.id platform and how they experience and how to implement or interpret tasks like a professional journalist. This research concluded that informants have experiences, motives, and meaning of citizen journalism by conducting citizen journalism activity regularly, therefore, they understand their role as a citizen journalist.
\end{abstract}

Keywords: citizen journalism, experience, journalist, meaning, motives, netcj

\begin{abstract}
Abstrak
Jurnalisme warga memang bisa dikatakan baru jika dibandingkan dengan jurnalisme tradisional. Namun, yang disebut baru bukan berarti baru muncul satu atau dua tahun yang lalu. Setelah dikenal melalui radio, jurnalisme warga berkembang ke ranah televisi sejak dikenalkan oleh melalui video amatir yang ditayangkan pada program berita Metro $T V$. Saat ini NET TV melalui program NET10 dan platform Netcj.co.id juga mengusung konsep jurnalisme warga yang saling berintegrasi. Walaupun jurnalisme warga memang bukan sesuatu yang baru, tetapi platform netcj.co.id yang menampung hasil liputan jurnalis warga masih terbilang baru. Oleh karena itu peneliti ingin mengetahui pandangan dari jurnalis warga netcj.co.id bagaimana mereka memaknai praktik jurnalisme warga dan peran dari seorang jurnalis warga. Selain itu, peneliti juga ingin mengetahui motif jurnalis warga dalam mengirimkan hasil liputan ke platform netcj.co.id dan bagaimana pengalaman serta cara mereka saat melaksanakan atau memaknai tugas layaknya seorang jurnalis profesional. Ketika menjalankan aktivitas jurnalisme warga secara rutin, para informan memperoleh pengalaman, motif, dan makna jurnalisme warga, sehingga mereka memahami perannya sebagai jurnalis warga.
\end{abstract}

Kata Kunci: jurnalisme warga, makna, motif, netcj, pengalaman

\section{Pendahuluan}

Bencana tsunami yang menimpa Aceh pada tahun 2004 direkam oleh seorang warga biasa. Video tersebut direkam oleh Cut Putri kemudian ditayangkan di MetroTV dan menjadi sumber tercepat dalam mengetahui peristiwa bencana tersebut. Dalam buku Mapping Digital http://jurnal.unpad.ac.id/kajian-jurnalisme | 245 
246 | Kajian Jurnalisme

ISSN 2549-0559 (cetak) ISSN 2549-1946 (online)

Volume 02 Nomor 02 Tahun 2019

Media: Citizen Journalism and the Internet (2011: 9) karya Nadine Jurrat' yang dilakukan oleh Cut Putri disebut sebagai citizen journalism (jurnalisme warga). Istilah jurnalisme warga digunakan pertama kali saat foto dan video mengenai peristiwa tsunami yang diunggah secara pribadi ditayangkan oleh stasiun televisi.

Mengenai jurnalisme warga, Shayne Bowman \& Chris Willis (2003) menjelaskan definisi jurnalisme warga sebagai "...the act of citizens playing an active role in the process of collecting, reporting, analyzing, and disseminating news and information" dapat diartikan jurnalisme warga merupakan peran aktif warga dalam mencari, mengumpulkan, melaporkan dan menganalisis berita untuk kemudian disebarkan kepada masyarakat luas melalui media.

Saat ini, NET TV merupakan stasiun televisi yang memiliki konsep jurnalisme warga dan terintegrasi dengan platform khusus, yaitu netcj.co.id pada berbagai program beritanya. Dengan membuat akun di platform tersebut anggota yang disebut NET Citizen Journalist (NETCJ) atau jurnalis warga dapat mengunggah hasil liputannya. Hasil liputan tersebut dapat tayang di program berita NET, yang memiliki segmen khusus jurnalisme warga adalah NET10.

Sebelum adanya jurnalisme warga di televisi, berdasarkan penelitian yang dilakukan oleh Moch Nunung Kurniawan berjudul Jurnalisme Warga di Indonesia Prospek dan Tantangannya (2007), di Indonesia stasiun radiolah yang memulai jurnalisme warga. Beberapa stasiun radio yang lebih dulu memulai konsep jurnalisme warga adalah Radio Mora FM di Bandung. Setelah itu, diikuti oleh radio Suara Surabaya. Pada tahun 2000-an radio Elshinta juga mengusung konsep jurnalisme warga.

Di ranah televisi, konsep jurnalisme warga mulai dikenalkan oleh Metro TV melalui video amatir yang ditayangkan pada program berita Metro TV. Kemudian sejak akhir April 2008 format jurnalisme warga ditayangkan pada program IWitness. Lalu, IWitness berganti menjadi Wideshot yang mulai tayang pada tahun 2012, tetapi programnya sudah tidak berjalan lagi sejak 2015 berdasarkan update yang ada dalam situs http://video.metrotvnews.com/wideshot/videos.

Konsep jurnalisme warga juga diusung oleh NET TV sejak tahun 2014 dan masih bertahan hingga saat ini. Jurnalisme warga yang diusung oleh NET TV berbeda dengan televisi lain. Stasiun televisi ini membuat sebuah sistem yang membuat jurnalis warga dan redaksi NET TV saling berkorelasi. Dalam penelitian yang dilakukan oleh Mahasiswa Universitas Padjadjaran, Dinar Safa Anggraeni (2016) yang berjudul Aktivasi Keterlibatan Publik dalam Program Berita 'NET 10' korelasi yang dilakukan oleh jurnalis warga dan redaksi adalah melalui kurasi yang dilakukan oleh redaksi terhadap video berita yang dikirimkan oleh jurnalisme warga di netcj.co.id.

Dengan mengirimkan videonya ke platform netcj.co.id, video yang diunggah memang dilakukan oleh warga Indonesia, baik yang di dalam maupun di luar negeri. Pemberitaan atau hasil tangkapan peristiwa yang mereka berikan ke netcj.co.id juga beragam. Keberagaman itu bisa terlihat di platform netcj.co.id dan program berita NET 10. Program NET 10 merupakan program berita yang memang fokus menayangkan berita hasil dari jurnalis warga. 
Kajian Jurnalisme

ISSN 2549-0559 (cetak) ISSN 2549-1946 (online)

Volume 02 Nomor 01 Tahun 2019

Dibandingkan stasiun televisi lain, saat ini NET TV masih konsisten dan memiliki durasi penayangan yang cukup panjang dalam menayangkan berita hasil dari jurnalis warga melaui program NET10. Sebagai televisi yang bersiaran secara nasional, tayangan jurnalisme warga dapat disaksikan di program NET10 yang tayang setiap hari Senin-Jumat pukul 10.0011.00 WIB. NET 10 selalu menyajikan berita dari jurnalis warga karena program tersebut memang memiliki segmen khusus mengenai jurnalisme warga dan menantang pemirsanya untuk membuat suatu karya jurnalis warga .

Tidak semua stasiun televisi yang bersiaran secara nasional memiliki program atau tayangan berita yang dibuat oleh warga. Berdasarkan pengamatan peneliti dari Februari-April 2018, terdapat 15 stasiun televisi yang bersiaran secara nasional, yaitu, Indosiar, RCTI, SCTV, Metro TV, Trans TV, ANTV, Trans 7, GTV, TV One, MNCTV, INews, TVRI, KompasTV, Rajawali TV, dan NET. Dari 15 stasiun televisi tersebut hanya 4 stasiun televisi yang memiliki program maupun tayangan berita dari jurnalis warga, yaitu: NET TV, Metro TV, TVRI, dan Trans 7.

Jurnalisme warga memang bisa dikatakan baru jika dibandingkan dengan jurnalisme tradisional. Namun, yang disebut baru bukan berarti baru muncul satu atau dua tahun yang lalu. Jurnalisme warga memiliki perkembangannya tersendiri dan sudah dimulai sejak tahun 1700-an akhir (Nugraha, 2012:8). Menurut Gillmor akar dari jurnalisme warga (citizen journalism) ini dimulai ketika warga menyebarkan tulisan dan gagasannya melalui pamflet. Akan tetapi itu bukan awal tumbuhnya citizen journalism, hanya sebagai akar di mana warga melaporkan berita. Gillmor menambahkan, Thomas Paine dan para penulis tak bernama (anonim) yang menulis gagasannya pada media Federalist Papers merupakan citizen journalism atau pewarta warga pertama di Amerika atau setidaknya "akar" jurnalisme warga.

Walaupun jurnalisme warga memang bukan sesuatu yang baru, tetapi platform netcj.co.id yang menampung hasil liputan jurnalis warga masih terbilang baru. Oleh karena itu, peneliti ingin mengetahui pandangan dari jurnalis warga netcj.co.id bagaimana mereka memaknai praktik jurnalisme warga (citizen journalism) dan peran dari seorang jurnalis warga (citizen journalist), Selain itu, peneliti juga ingin mengetahui motif jurnalis warga netcj.co.id dalam mengirimkan hasil liputan ke plaform netcj.co.id dan peneliti juga ingin mengetahui bagaimana pengalaman serta cara mereka saat melaksanakan atau memaknai tugas layaknya seorang jurnalis profesional.

Pada penelitian ini peneliti menguraikan bagaimana pengalaman aktivitas jurnalisme warga yang para subjek lakukan dalam membentuk makna tersendiri. Pengalaman para informan atau subjek penelitian saat awal mula mengenal jurnalisme warga dan memperoleh pengalaman, menemukan motif menjalankan aktivitas jurnalisme warga, hingga memaknai aktivitas jurnalisme warga. Ketiga proses tersebut menjadi satu kesatuan dalam suatu tahapan untuk memaknai aktivitas jurnalisme bagi para informan secara subjektif.

\section{Metode}

Penelitian ini menggunakan metode penelitian kualitatif dengan pendekatan fenomenologi. Peneliti memilih menggunakan metode kualitatif karena sesuai dengan karakteristik 
248 | Kajian Jurnalisme

ISSN 2549-0559 (cetak) ISSN 2549-1946 (online)

Volume 02 Nomor 02 Tahun 2019

penelitian kualitaiif, seperti latar belakang alamiah warga yang ingin menjadi jurnalis warga, peneliti sebagai pengumpul data, dalam memperoleh data peneliti melakukan wawancara dan pengamatan terhadap jurnalis warga yang tergabung di netcj.co.id, hasilnya pun akan berupa kata-kata, bukan angka-angka.

Dalam penelitian ini, peneliti menggunakan pendekatan fenomenologi karena subjek penelitian atau dalam peneltian ini adalah jurnalis warga untuk mengetahui tindakan jurnalis warga dalam melaksanakan liputan. Dari kegiatan tersebut, jurnalis warga membentuk pemaknaan mengenai citizen journalism (jurnalisme warga). Selain dengan menggunakan pendekatan fenomenologi, peneliti juga memakai teori konstruksi realitas sosial sebagai pisau analisis penelitian ini.

Dalam teori yang telah disebutkan realitas sosial dikonstruksi melalui proses eksternalisasi, objektivasi, dan internalisasi (Bungin, 2008:192). Kaitannya dengan konsep tersebut, jurnalis warga juga memiliki realitas yang dikonstruksi melalui ketiga proses tersebut. Pada proses eksternalisasi terjadi pada saat jurnalis warga melakukan liputan dan memiliki motif serta alasan untuk menjadi seorang jurnalis warga (citizen journalist). Kemudian proses objektivasi terjadi saat jurnalis warga melakukan interaksi dengan narasumber saat liputan. Lalu, proses internalisasi yang dihasilkan dari proses eksternalisasi dan objektivasi yaitu, pemaknaan yang dimiliki jurnalisme warga setelah melakukan tugastugas seorang jurnalis.

Dari berbagai pendekatan dan teori yang digunakan peneliti mengumpulkan data dengan beberapa teknik, yaitu observasi, wawancara, dan studi kepustakaan. Dalam melakukan wawancara peneliti menentukan informan berasarkan kriteria. Adapun kriteria informan yang telah peneliti tetapkan adalah bukan seorang jurnalis profesional atau belum pernah menjadi jurnalis profesional, memiliki akun netcj.co.id, hasil liputannya pernah tayang dalam program berita di NET, mampu menceritakan kembali pengalaman yang dialami, dan bersedia untuk diwawancara.

Peneliti mewawancarai lima orang yang memenuhi kriteria yang telah disebutkan. Lima informan tersebut adalah jurnalis warga yang berasal dari beberapa daerah. Informan pertama dari Depok, Jawa Barat; kedua dari Jakarta; ketiga dari Bandung; keempat dari Yogyakarta; dan kelima dari Yogyakarta. Pertanyaan dalam wawancara mendalam yang peneliti ajukan berkaitan dengan proses kerja, pemaknaan, dan bentuk sosialisasi yang diterapkan saat melakukan liputan. Wawancara mendalam ini dilakukan seara informal berupa percakapan (interaktif), dan pertanyaan serta jawaban terbuka. Setelah itu peneliti menguji keabsahan data dengan beberapa langkah, beberapa di antaranya adalah konfirmasi kepada beberapa peneliti lain dan menggolongkan data di bawah data yang sama/cocok

\section{Hasil dan Pembahasan}

Pada bagian ini peneliti menjabarkan bagaimana proses para informan penelitian memaknai jurnalisme warga. Pemaknaan mengenai jurnalisme warga diperoleh dari pengalaman yang telah para informan atau jurnalis warga alami. Tahapan atau proses tersebut peneliti interpretasikan dari hasil penelitian yang diperoleh melalui proses wawancara serta 
observasi. Dari hasil wawanacara dan observasi diperoleh data bahwa pengalaman yang para informan alami benar-benar merupakan pengalaman yang dialami oleh setiap informan. Para informan membuktikannya dengan menunjukkan hasil dari aktivitas jurnalisme warga yang mereka lakukan, yaitu hasil liputan mereka yang telah tayang.

Pembahasan ini mencakup hal yang memenuhi tujuan penelitian, yaitu mengenai pengalaman informan, motif, dan pemaknaan aktivitas jurnalisme warga. Ketiga hal tersebut merupakan realitas yang terkonstruksi oleh indivdiu dan implikasi bagi kehidupan mereka dengan orang lain, di mana setiap individu memiliki pengalaman yang unik. Pengalaman tersebut merupakan pengalaman yang dialami oleh masing-masing informan.

Seperti halnya fenomenologi yang mencari pemahaman bagaimana manusia mengkonstruksi makna. Proses informan dalam memaknai aktivitas jurnalisme warga merupakan suatu konstruksi dari pengalaman yang mereka alami. Proses memperoleh makna jurnalisme warga berkaitan dengan bagaimana informan memperoleh pengetahuan mengenai jurnalisme warga dan penyesuaian diri terhadap lingkungan. Jika dikaitkan dengan tiga tahapan dari konstruksi realitas Peter L Berger dan Thomas Luckmann proses yang informan alami mewakili proses intersubjektif dalam konstruksi realitas sosial. Proses intersubjektif meliputi momen dialektis yang simultan, yaitu ekternalisasi, objektivasi, dan internalisasi.

\section{Pengetahuan Mengenai Jurnalisme Warga}

Pertama, yaitu eksternalisasi terjadi ketika informan mulai mencari tahu perihal aktivitas jurnalisme warga. Dalam hal ini informan memilih platform netcj.co.id dalam mencari tahu perihal jurnalisme warga. Pencarian tersebut informan lakukan untuk mempersiapkan mental dan menetapkan diri melakukan aktivitas jurnalisme warga, yaitu dengan menjadi jurnalis warga. Persiapan tersebut juga mencakup motif yang informan tetapkan untuk melakukan aktivitas jurnalisme warga.

Setelah mencari tahu mengenai jurnalisme warga, para informan mulai melakukan proses penyesuaian diri dengan dunia sosio-kultural. Pada penelitian ini dunia sosio-kultural yang dimaksud adalah dunia jurnalistik, yaitu melakukan liputan layaknya jurnalis profesional. Dari proses tersebut informan memperoleh pengalaman sebagai pengetahuan awal mengenai jurnalisme warga.

Berdasarkan hasil penelitian, penjabaran mengenai proses ekternalisasi terlihat dari bagaimana setiap informan mencari tahu mengenai jurnalisme warga. Para informan memiliki cara yang berbeda untuk mengenal dunia sosio-kulturalnya. Di antaranya adalah dengan menonton tayangan berita, menghadiri seminar, mencari tahu melalui individu lain, dan melalui penelusuran di internet.

Informan pertama, mengenal dunia jurnalistik karena suka menonton tayangan berita. Dari menonton tayangan berita, informan tertarik menjalankan aktivitas jurnalistik. Sampai ketika informan memiliki pengalaman dengan melaksanakan liputan, ia mulai memahami bahwa yang ia lakukan adalah aktivitas jurnalisme warga. Berbeda dengan informan pertama, informan kedua mencari tahu perihal jurnalisme warga melalui internet. Setelah mencari tahu 
250 | Kajian Jurnalisme

ISSN 2549-0559 (cetak) ISSN 2549-1946 (online)

Volume 02 Nomor 02 Tahun 2019

bagaimana prosedur menjadi seorang jurnalis warga, ia langsung turun mempraktikannya untuk memperoleh pengalaman menjadi jurnalis warga.

Pengenalan informan ketiga terhadap jurnalisme warga bukan karena suka menonton tayangan berita atau mencari tahu di internet, melainkan karena sang informan menghadiri seminar. Dalam seminar tersebut, informan memperoleh penjelasan mengenai jurnalisme warga dan cara untuk menjadi jurnalis warga di ranah televisi. Bagi informan yang menyukai videografi, ia tak segan untuk langung mempraktikkan dengan meliput suatu kegiatan seminar. Itulah pengalaman pertama informan menjadi jurnalis warga.

Informan ke empat dan ke lima mencari tahu mengenai jurnalisme warga dari temannya yang lebih dahulu menjalankan aktivitas jurnalisme warga. Keduanya mempelajari dan langsung melakukan liputan dengan teman yang memberikan informasi agar memiliki pengalaman terlebih dahulu. Setelah memperoleh pengalaman dari teman yang memberikan informasi perihal jurnalisme warga perlahan kedua informan melakukan aktivitas jurnalisme warga masing-masing.

Setelah mengenal jurnalisme warga dan melakukan aktivitas jurnalisme warga, proses ekternalisasi ini juga membuat kelima informan mulai memahami adanya suatu proses dalam melakukan aktivitas jurnalisme warga terutama dalam hal liputan. Proses tersebut adalah cara mereka mencari topik untuk liputan, mewawancarai narasumber, kemudian pengambilan gambar, penulisan naskah, hingga proses editing dan mengirimkan hasil liputan ke netcj.co.id. Dari proses itulah tercipta pengalaman yang dialami masing-masing informan untuk memaknai jurnalisme warga.

Dari penjelasan di atas, menurut pandangan Berger dan Luckmann perlu diketahui bahwa eksternalisasi adalah proses penyesuaian diri dengan dunia sosio-kultural sebagai produk manusia (2013: xx). Dalam penelitian ini hasil proses ekternalisasi informan adalah melihat jurnalisme warga sebagai produk sosial. Ekternalisasi juga merupakan usaha pencurahan atau ekpresi diri manusia ke dalam dunia sosio-kultural, baik dalam kegiatan mental maupun fisik.

Selanjutnya, seperti yang sudah disebutkan di atas bahwa dalam persiapan memaknai aktivitas jurnalisme warga para informan memiliki motif untuk meyakinkan dirinya menjadi jurnalis warga. Memiliki motif juga merupakan hal penting yang menjadi bagian dari ekternalisasi karena menjadi sesuatu yang mendasari para informan dalam memaknai aktivitas jurnalisme warga. Burhan Bungin (2008: 194) menjelaskan bahwa eksternalisasi adalah bagian penting dalam kehidupan individu dan menjadi bagian dari dunia sosiokulturalnya. Ekternalisasi terjadi pada tahap yang sangat mendasar dalam suatu pola perilaku interaksi antara individu dengan produk-produk sosial masyarakatnya. Maksud dari proses ini adalah ketika produk sosial telah menjadi sebuah bagian penting dalam masyarakat yang setiap saat dibutuhkan oleh individu, maka produk sosial itu menjadi bagian penting dalam kehidupan seseorang untuk melihat dunia luar.

Dari hasil penelitian yang peneliti lakukan, para informan memiliki motif yang tidak jauh berbeda sebelum menjalankan aktivitas jurnalisme warga. Motif tersebut adalah mendapatkan honorarium, mempelajari serta mencari pengalaman di bidang jurnalis, dan juga 
Kajian Jurnalisme

ISSN 2549-0559 (cetak) ISSN 2549-1946 (online)

Volume 02 Nomor 01 Tahun 2019

menyalurkan hobi. Dalam fenomenologi, motif ini masuk dalam fase because motive atau motif masa lalu atau dalam tipologi Shaun Sutton ketiga motif tersebut masuk dalam kategori motif kepuasan pribadi dan pengembangan pribadi.

Para informan mengakui bahwa mereka tertarik menjadi jurnalis warga netcj.co.id (NETCJ) karena jika hasil liputan mereka tayang dalam program berita NET mereka bisa memperoleh honorarium. Honorarium tersebut memang disebutkan dalam ketentuan yang tertera dalam website netcj.co.id. Keinginan memperoleh honorarium memang menarik perhatian para informan, tetapi ada juga informan yang tidak mengincar honorarium untuk menjalankan aktivitas jurnalisme warga.

\section{Produk Sosial Sebagai Realitas Objektif}

Setelah melalui tahap ekternalisasi, tahap lanjutan dari proses dialektika adalah objektivasi. Objektivasi merupakan hasil yang telah dicapai baik mental maupun fisik dari kegiatan eksternalisasi manusia tersebut, yaitu produk sosial. Produk sosial itu berupa realitas yang objektif, yang berbeda dengan kenyataan subjektif perorangan. Pada tahap ini produk sosial dilihat sebagai realitas yang objektif (Society is an objective reality) atau proses interaksi sosial dalam dunia intersubjektif yang dilembagakan atau mengalami proses institusionalisasi. Sedangkan individu menurut Berger dan Luckmann (2013:47) memanifestasikan diri dalam produk-produk kegiatan manusia yang tersedia, baik bagi produsen-produsennya maupun bagi orang lain sebagai unsur dari dunia bersama.

Proses objektivasi yang termasuk dalam penelitian ini adalah saat para informan mulai menjalankan aktivitas jurnalisme warga. Dengan melakukan aktivitas jurnalisme warga terutama liputan, para informan mulai melakukan interaksi dengan narasumber (dalam penelitian bisa disebut sebagai masyarakat), sesama jurnalis warga, atau dengan jurnalis profesional, sehingga para informan mampu menyesuaikan diri dan beradaptasi dengan dunia sosiokulturalnya. Proses penyesuaian diri para informan dapat bertahan hingga jangka waktu yang lama seperti yang Berger dan Luckman (2013: 47) jelaskan bahwa tahap objektivasi ini bertahan lama sampai melampaui batas tatap muka di mana mereka dapat dipahami secara langung.

Dalam tahap tersebut, para informan mulai memasuki tahapan masyarakat yang dilembagakan dan berada dalam proses institusionalisasi. Kelima informan menjadi masyarakat yang dilembagakan dengan menjadi jurnalis warga dan memiliki rutinitas layaknya jurnalis profesional, yaitu liputan. Para jurnalis warga tersebut menjalankan aktivitas jurnalisme warga dengan melakukan liputan yang membuat adanya interaksi dengan sesama jurnalis warga, narasumber, bahkan dengan jurnalis profesional.

Dari pengalaman para informan, mereka memang merasa memiliki kesulitan saat memasuki tahap ini. Dua orang informan saat awal menjalankan aktivitas jurnalisme warga merasa ragu dan takut dalam mewawancarai seseorang yang ingin dijadikan narasumber. Informan lain, memiliki kendala dalam melobi narasumber. Lain halnya dengan dua informan lain yang saat awal melakukan liputan masih belum memahami bagaimana mengoperasikan 
252 | Kajian Jurnalisme

ISSN 2549-0559 (cetak) ISSN 2549-1946 (online)

Volume 02 Nomor 02 Tahun 2019

alat yang ia miliki. Sedangkan lainnya justru bisa memulai interaksi dengan baik dengan jurnalis profesional yang ia temui saat liputan.

Setelah melakukan aktivitas jurnalisme warga selama beberapa waktu, para informan mulai mengetahui bagaimana menghadapi kendala yang mereka alami dengan melakukan aktivitas jurnalisme warga secara rutin. Dengan melakukan secara rutin berarti para informan telah menjadikan aktivitas jurnalisme warga sebagai suatu kebiasaan yang terus dilakukan secara berulang. Aktivitas yang dilakukan secara berulang tersebut di antaranya adalah melakukan liputan, baik dari segi persiapan maupun teknis di lapangannya. Proses di atas merupakan proses pelembagaan karena pelembagaan menurut Berger dan Luckmann (2013: 72) bermula saat manusia mengalami proses pembiasaan (habitualisasi).

Pembiasaan ini selanjutnya berarti bahwa tindakan yang telah para infoman lakukan bisa dilakukan di masa mendatang dengan cara yang sama dan dengan upaya yang sama ekonomisnya (Berger dan Luckmann, 2013: 72). Dari pernyataan tersebut jelas bahwa para informan masuk dalam tahap pelembagaan dengan melakukan aktivitas jurnalisme warga secara berulang. Para informan juga membuktikannya dengan terus melakukan aktivitas jurnalis warga selama bertahun-tahun, artinya aktivitas jurnalisme warga yang informan lakukan bisa terus dilakukan di masa mendatang. Semua aktivitas jurnalisme warga yang telah para informan lakukan, seperti liputan dan mewawancarai narasumber masuk dalam tahapan objektivasi karena adanya interaksi sosial sebagai bagian dari dunia sosiokultural yang menjadi lembaganya.

Selain pelembagaan, hal terpenting yang dalam tahap objektivasi adalah pembuatan signifikasi, yakni pembuatan tanda-tanda oleh manusia. Menurut Berger dan Luckman (2013: 48) sebuah tanda dapat dibedakan dari objektivasi-objektivasi lainnya, karena tujuan yang eksplisit untuk digunakan sebagai isyarat atau indeks bagi makna-makna subjektif. Pembuatan signifikasi atau tanda-tanda oleh manusia pada penlitian ini dilakukan oleh para informan saat mereka melakukan liputan sebagai jurnalis warga. Tanda-tanda atau signifikasi mereka lakukan terhadap aktivitas jurnalisme warga yang mereka kerjakan sebagai cara untuk berinteraksi sosial.

Sebagai contoh, informan jurnalis warga dari Bandung, untuk meyakinkan seseorang di lokasi liputan bahwa dirinya meliput sebagai jurnalis warga, ia menggunakan baju yang bertuliskan citizen journalism. Dengan menunjukkan tulisan yang ada di baju tersebut informan tersebut dapat melakukan liputan layaknya jurnalis profesional yang menunjukkan kartu persnya. Kondisi tersebut menunjukkan sang inforan telah menciptakan tanda lain yang dapat membuat orang mengerti bahwa dirinya melakukan aktivitas jurnalisme warga, yaitu liputan.

Berbeda dengan informan dari Bandung tanda-tanda atau signifikasi lainnya juga dilakukan oleh informan jurnalis warga dari Yogyakarta. Informan ini meciptakan tanda dengan melakukan lobi kepada pemilik lokasi yang ingin ia jadikan lokasi liputan. Ia menjelaskan maksud untuk liputan dan menjelaskan tentang jurnalisme warga dengan memberi tahu bahwa hasil liputan akan dikirim ke NET dan diseleksi untuk bisa tayang. 
Selain itu, sang informan juga memberikan hasil liputan yang sudah tayang sebagai contoh agar mudah dipahami.

Kedua contoh di atas merupakan cara para informan dalam memahami aktivitas jurnalisme warga. Pembuatan tanda-tanda tersebut diperoleh saat para informan melakukan liputan, karena adanya interaksi sosial yang terjadi saat melakukan liputan. Dari hasil wawancara dan observasi yang telah peneliti lakukan, tanda-tanda atau siginifikasi yang para informan dapatkan tidak semuanya sama. Oleh karena itu, pengalaman yang diperoleh para informan tidak begitu berbeda satu sama lain.

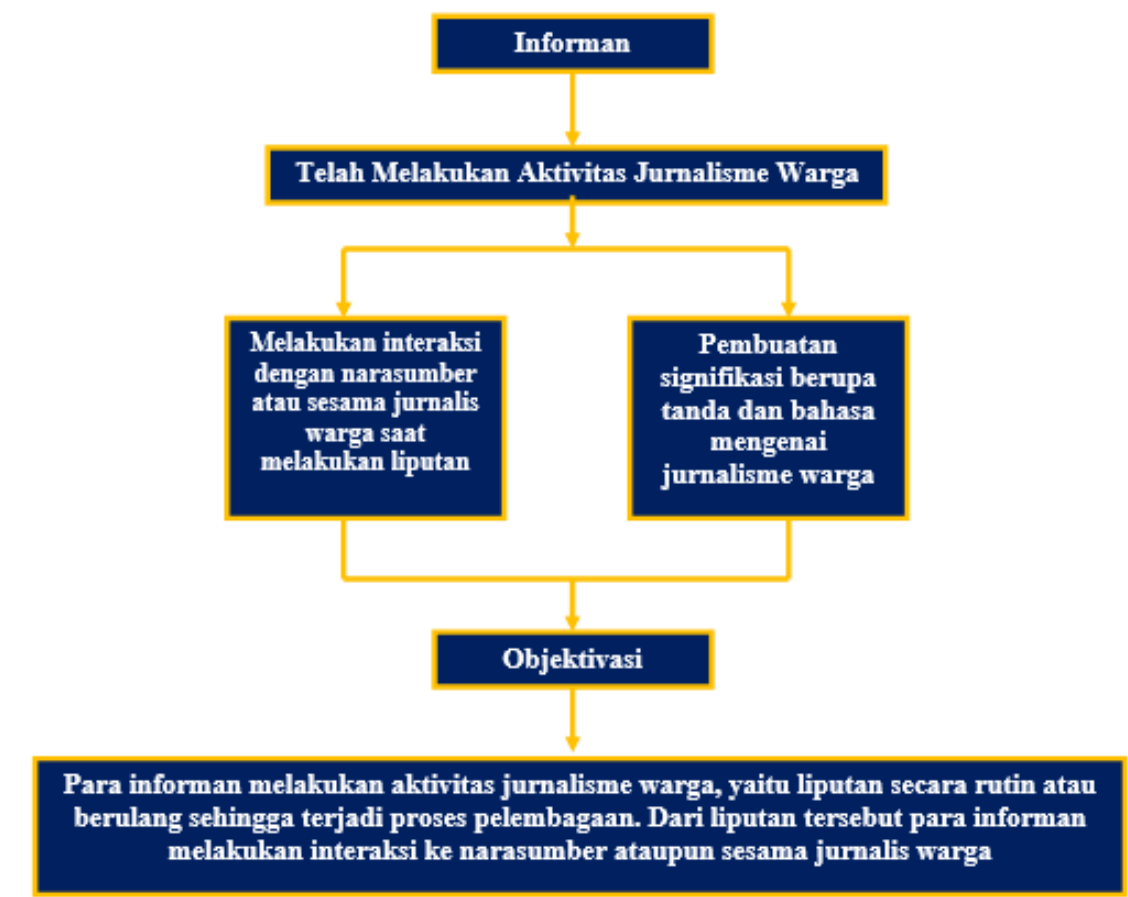

Diagram 4.5 Pengalaman Jurnalis Warga saat Liputan (Sumber: Hasil Elaborasi Peneliti)

\section{Momen Internalisasi}

Dua tahapan dalam proses dialektika yang sudah dijelaskan sebelumnya adalah ekternalisasi dan objektivasi. Ekternalisasi merupakan proses penyesuaian diri para informan dengan dunia sosio-kulturalnya. Sedangkan objektivasi adalah tahapan di mana para informan melakukan rutinitas yang berulangatau terus-menerus dialami oleh para informan. Ekternalisasi dan objektivasi merupakan momen-momen dalam suatu proses dialektis yang berlangsung terus menerus (Berger dan Luckmann, 2013: 83). Setelah ekternalisasi dan objektivasi momen ketiga dalam proses ini adalah internalisasi.

Momen ketiga yaitu internalisasi, di mana dunia sosial yang sudah diobjektivasi dimasukkan kembali ke dalam kesadaran selama berlangsungnya sosialisasi (Berger dan Luckmann, 2013: 82). Secara sederhana dapat dijelaskan bahwa intenalisasi lebih mengarah kepada penyerapan kembali dunia objektif ke dalam kesadaran manusia. Dalam penelitian ini, http://jurnal.unpad.ac.id/kajian-jurnalisme 
254 | Kajian Jurnalisme

ISSN 2549-0559 (cetak) ISSN 2549-1946 (online)

Volume 02 Nomor 02 Tahun 2019

para informan menyesuaikan diri dengan dunia sosio-kultural atau dengan dunia jurnalistik dengan melakukan aktivitas jurnalisme warga (ekternalisasi). Kemudian, melakukan rutinitas yang berulang, seperti liputan, wawancara, editing, dan menyebarkan hasil liputan (objektivasi). Setelah itu, para informan menyerap kembali semua proses tersebut dan memaknai aktivitas jurnalisme warga sebagai kenyataan subjektif (internalisasi).

Berdasarkan penjelasan di atas, informan dalam penelitian ini memasuki tahap internalisasi ketika para informan memiliki pemaknaan terhadap aktivitas jurnalisme warga. Jika pada proses ekternalisasi para informan masih dalam tahap penyesuaian, pada tahap internalisasi ini para informan memiliki pemaknaan mengenai jurnalisme warga dari aktivitas yang telah para informan kerjakan. Pemaknaan yang kelima informan miliki tidak berbeda jauh satu sama lain.

Jurnalisme warga menurut informan pertama adalah kegiatan yang dapat mengisi waktu luang. Ia juga menyebutkan bahwa hasil dari aktivitas jurnalisme warga merupakan sesuatu yang bagus dan bisa menjadi alternatif pemberitaan. Informan kedua memiliki penjelasan berbeda mengenai jurnalisme warga. Menurutnya, melakukan aktivitas jurnalisme warga berarti jurnalis warga bisa berkontribusi bagi masyarakat dengan meliput hal atau peristiwa yang bisa mengimbau serta mengedukasi masyarakat.

Penjelasan senada mengenai jurnalisme warga juga dipaparkan oleh informan ketiga. Ia menjelaskan pandangannya mengenai jurnalisme warga sebagai kegiatan layaknya jurnalis profesional yang dilakukan oleh warga yang tidak terikat oleh media tertentu. Bagi sang informan, meskipun tidak terikat media tertentu, jurnalisme warga merupakan wadah yang memberikan kesempatan warga sebagai jurnalis non-profesional untuk berkarya.

Informan keempat menganggap bahwa jurnalisme warga merupakan aktivitas jurnalistik yang memiliki kelebihan, berupa kecepatan meliput berita apabila terjadi peristiwa di lingkungannya, serta keunikan topik yang diliput. Informan kelima juga memaknai jurnalisme warga sebagai keterlibatan warga dalam meliput keadaan sekitar yang dapat membuat perubahan. Ia juga menjelaskan bahwa menjadi jurnalis warga berarti tidak terikat dengan media tertentu.

Dari pemaknaan yang telah para informan sampaikan, terdapat beberapa hal yang bisa menjadi sorotan. Di antaranya adalah bahwa jurnalisme warga dilakukan oleh warga, bukan dari jurnalis profesional, dan melakukan kegiatan layaknya jurnalis profesional. Poin-poin tersebut memang menjadi poin utama dalam menjalankan aktivitas jurnalisme warga. Jay Rosen (2008) menjelaskan, jurnalisme warga merupakan "When the people formerly known as the audience employ the press tools they have in their possession to inform one another" atau yang bisa diartikan bahwa jurnalis warga merupakan seseorang (warga) yang dulunya hanya sebagai penonton atau audiens yang melakukan kegiatan pers pencarian, pengumpulan, pelaporan, pembuatan) dan ingin membagikan informasi kepada orang lain.

Para informan yang mengalami proses internalisasi seperti yang dijelaskan di atas mengalami sebuah proses yang biasa disebuut dengan sosialiasi. Berger dan Luckmann (2013: 178) menjelaskan, sosialiasi dapat didefinisikan sebagai pengimbahasan individu secara komprehensif dan konsisten ke dalam dunia objektif suatu masyarakat atau salah satu 
Kajian Jurnalisme

ISSN 2549-0559 (cetak) ISSN 2549-1946 (online)

Volume 02 Nomor 01 Tahun 2019

sektornya. Dalam proses sosialisasi ini terbagi menjadi dua sosialiasi, yaitu primer dan sekunder.

Sosialisasi primer sendiri merupakan sosialisasi pertama yang dialami oleh individu dan biasanya merupakan sosialisasi yang penting bagi individu. Sosialisasi ini menjadi penting karena merupakan proses di mana individu terlibat dengan dunia sosial lebih dari belajar secara kognitif semata, karena individu mengidentifikasikan dirinya dengan orangorang yang memengaruhinya dengan berbagai cara yang emoisional. Melalui identifikasi dengan orang yang berpengaruh, individu mampu memperoleh suatu identitas yang subjektif koheren dan masuk akal (Berger dan Luckmann, 2013: 178-180).

Para informan dalam penelitian ini mengalami sosialisasi primer saat informan memasuki dunia sosio-kultural di mana para informan mulai mempersiapakn dirinya untuk melakukan aktivitas jurnalisme warga. Tahap ini menjadi penting karena sebelum menjalani tahapan selanjutnya seluruh informan memilih cara mereka untuk mempelajari tentang jurnalisme warga. Cara mereka adalah dengan bertanya kepada orang-orang yang dipercayai maupun melakukan praktik jurnalisme warga dan berinteraksi dengan orang-orang yang ditemui saat liputan. Sebagai tahapan yang penting, sosialiasi primer para informan juga dialami ketika informan memiliki motif untuk menjalankan aktivitas jurnalisme warga.

Setelah para informan bergabung dalam masyarakat dan secara subjektif sadar telah menjadi jurnalis warga serta menjalankan aktivitas jurnalisme warga, maka sosialiasi primer para informan berakhir. Menurut Berger dan Luckmann, sosialisasi primer berakhir apabila konsep tentang orang lain pada umumnya dan segala sesuatu yang menyertainya telah terbentuk dan tertanam dalam kesadaran individu.Pada titik ini sudah merupakan anggota efektif masyarakat dan secara subjektif memiliki suatu diri dan sebuah dunia.

Internalisasi berikutnya terjadi pada proses sosialisasi sekunder. Sosialisasi sekunder adalah intenalisasi sejumlah "sub-dunia" yang berlandaskan lembaga. Lingkup jangkauan dari sosialisasi ini dan sifatnya ditentukan oleh kompleksitas pembagian kerja dan distribusi pengetahuan dalam masyarakat yang menyertainya. Pada sosialisasi ini individu memperoleh pengetahuan khusus sesuai dengan perannya, di mana peran-peran secara langsung berakar dari pembagian kerja (Berger dan Luckmann, 2013: 188)

Berlandaskan pernyataan di atas, sosialisasi sekunder yang terjadi pada informan dalam penelitian ini terjadi saat para informan memperoleh pengetahuan khusus sesuai perannya. Peran tersebut adalah sebagai jurnalis warga yang menjalankan aktivitas jurnalisme warga. Sebagai jurnalis warga, dalam menjalankan aktivitas jurnalisme warga para informan memiliki pengetahuan khusus, yaitu ketika para informan dapat memaknai jurnalisme warga. Pemaknaan itu diperoleh setelah melakukan liputan dan memiliki pengalaman menjalankan aktivitas jurnalisme warga.

Berdasarkan hasil penelitian, pengetahuan khusus lainnya sebagai bentuk internalisasi sosialiasi sekunder yang informan miliki dari pemaknaan terhadap aktivitas jurnalisme warga di antaranya adalah pengetahuan mengenai bidang jurnalistik, pola dalam melakukan aktivitas jurnalisme warga, dan pengetahuan mengenai motif dalam menjalankan aktivitas jurnalisme warga. Dengan sendirinya pengetahuan proses internalisasi ini melibatkan 
256 | Kajian Jurnalisme

ISSN 2549-0559 (cetak) ISSN 2549-1946 (online)

Volume 02 Nomor 02 Tahun 2019

identifikasi subjektif dengan peran sebagai jurnalis warga. Akan tetapi, tidak seperti sosialisasi primer yang tidak dapat berlangsung tanpa identifikasi yang bermuatan emosi, kebanyakan sosialisasi sekunder tidak memerlukan identifikasi semacam itu dan bisa berlangsung secara efektif dengan hanya identifikasi timbal-balik dalam tiap komunikasi antar manusia (Berger dan Luckmann, 2013: 190-192).

\section{Simpulan}

Berdasarkan penelitian yang telah peneliti lakukan dan hasil penelitian yang telah dijabarkan, simpulan dari penelitian ini adalah pengalaman kelima informan dalam mengenal aktivitas jurnalisme warga cukup berbeda. Proses pengenalan kelima informan peroleh dari menonton hasil liputan jurnalis warga yang ditayangkan di televisi, memperoleh informasi dari internet, dan mencari tahu melalui rekan yang telah menjalankan aktivitas jurnalisme warga lebih dahulu. Kelima informan memiliki pengalaman dalam menjalankan aktivitas jurnalisme warga, terutama mengenai kendala. Para informan realitasnya mengalami kendala seperti pertanyaan berasal dari media mana dan kapan tayang, permintaan menunjukkan kartu pers, dan pemahaman masyarakat mengenai jurnalisme warga yang membuat para informan menyadari perbedaan antara jurnalis profesional dan jurnalis warga. Situasi yang dialami oleh para informan tercipta dari tiga tahapan dalam konstruksi realitas, yaitu eksternalisasi, objektivasi, dan internalisasi.

Penelitian ini juga menunjukkan, terdapat beberapa motif yang menjadi kecenderungan para informan dalam menjalankan aktivitas jurnalisme warga. Motif kepuasan pribadi dan pengembangan pribadi menjadi motif utama para informan dalam menjalankan aktivitas jurnalisme warga. Dalam pelaksanaannya para informan memiliki motif yang tidak melupakan tugas sebagai seorang jurnalis, yaitu motif penyebaran informasi dan perubahan sosial dengan cara menghadirkan konten alternatif dari segi topik pemberitaan.

Setelah itu, dengan menjadi jurnalis warga para informan dapat memaknai aktivitas jurnalisme warga dari pengalaman dan menjalani perannya sebagai jurnalisme warga secara rutin. Bagi kelima informan, jurnalisme warga merupakan aktvitas warga dalam menjalankan aktivitas seperti jurnalis profesional dengan cara meliput peristiwa di sekitar yang menarik dan layak menjadi konten jurnalistik. Para informan menganggap jurnalisme warga merupakan aktivitas yang dapat melatih warga untuk belajar menjadi jurnalis profesional. Selain itu, para informan juga memaknai jurnalisme warga sebagai alternatif pemberitaan media arus utama.

\section{Daftar Pustaka}

Ardianto, Elvinaro. Lukiati Komala, Siti Karlinah. (2009). Komunikasi Massa Suatu Pengantar. Bandung: Simbiosa Rekatama Media.

Baksin, Askurifai. (2013). Jurnalistik Televisi Teori dan Praktik. Bandung: Simbiosa Rekatama Media

Berger, Peter L \& Thomas Luckmann. (2013). Tafsir Sosial Atas Kenyataan: Risalah Tentang Sosiologi Pengetahuan. Jakarta: LP3ES.

Bungin, M. Burhan. (2008). Penelitian Kualitatif. Jakarta: Kencana Prenada Media

http://jurnal.unpad.ac.id/kajian-jurnalisme 
Kajian Jurnalisme

ISSN 2549-0559 (cetak) ISSN 2549-1946 (online)

Volume 02 Nomor 01 Tahun 2019

Cresswell, JohnW. (2007). Qualitative Inquiry \& Research Design Chosing Among Five Approaches (Second Edition). Thousand Oaks (California), London, New Delhi: Sage Publications

Gillmor, Dan. (2004). We the Media: Grassroots Journalism By the People For the People, United States of America: O'Reilly Media, Inc

Jurrat', Nadine. (2011). Mapping Digital Media: Citizen Journalism and the Internet. Cambridge: Open Society Foundations.

Kovach, Bill \& Tom Rosentiel. (2006). Sembilan Elemen Jurnalisme. Jakarta: Yayasan Pantau

Kuswarno, Engkus. (2009). Metode Penelitian Komunikasi: Fenomenologi, Konsepsi, Pedoman, dan Contoh Penelitiannya. Bandung: Widya Padjadjaran

Moustakas, Clark. (1994). Phenomenological Research Methods. California: Sage Publications Inc.

Nugraha, Pepih. (2012). Citizen Journalism Pandangan, Pemahaman, dan Pengalaman. Jakarta: Penerbit Buku Kompas.

Bowman, S. and Willis, C. (2003). We Media: How Audiences are Shaping the Future of News and Information. The Media Center, American Press Institute

Safa Anggraeni, Dinar. (2016). Aktivasi Keterlibatan Publik Dalam Program Berita 'Net 10'. Program Studi Jurnalistik, Fakultas Ilmu Komunikasi, Universitas Padjadjaran, Jatinangor

Sutton, Shaun. (2006). The 'My' in OhMyNews: A Uses and Gratifications Investigation Into the Motivations of Citizen Journalists in South Korea. University of Leeds United Kingdom

Yudhapramesti, Pandan. (2007). Citizen Journalism (CJ) Sebagai Media Pemberdayaan Warga. Majalah Observasi. Vol 5. No. 1, pp. 33-45

http://netcj.co.id/ diakses pada Rabu, 4 Oktober 2017

https://www.theguardian.com/media/2010/oct/11/andrew-marr-bloggers (diakses pada Rabu, 21 Maret 2018)

Nazmudin, Acep. "NET CJ Tembus 90000 Member". 4 Oktober 2017, pukul 23:00. http://wartakota.tribunnews.com/2016/02/26/net-cj-tembus-90000-member

Steve Outing, "The 11 Layers of Citizen Journalism," PoynterOnline, June 15 2005, www.poynter.org/11layer

http://jurnal.unpad.ac.id/kajian-jurnalisme 